\title{
Research on the Intervention of Positive Group Psychology Counseling on the Resilience of College Students
}

\author{
Lian Liu \\ Heihe University \\ Heihe, China
}

\author{
Xueying Zhang \\ Heihe University \\ Heihe, China
}

\author{
Lirong Song \\ Heihe University \\ Heihe, China
}

\begin{abstract}
Purpose: To discuss the influence of positive group psychology counseling on the resilience of college students. Method: Train the college students in the experimental group and the control group for eight weeks with the method of positive group psychology counseling. Result: After the group counseling, the resilience of the experimental group improves obviously. The total score of purpose concentration, emotional control, positive cognition, interpersonal assistance, personal strength and sustaining strength as well as the resilience changes obviously. Conclusion: The positive group psychology counseling plays a positive role in improving the college students' resilience.
\end{abstract}

Keywords-positive psychology; group psychology counseling; resilience

\section{INTRODUCTION}

With the upsurge of the positive psychology, the positive quality of people has received more and more attention. The mission of positive psychology changes, namely, how to enrich our life, discover and cultivate the gifted, let people see the positive strengths of their own and see more hope and power. As a positive psychological quality, the resilience has also been researched widely. According to the research report, the resilience plays an important role in responding to the pressure and keeping psychological health.

The definition of the resilience comes from three aspects, the result, the ability and the process. With respect to the result definition, the representative Maste addresses: Although when an individual is in the situation with high risk, he can also develop and adapt very well; as for the ability definition, the representative Germezy states, "an individual can bear the pressure from the high risk and show the ability in proper adjustment"; in regard to the process, the representative regards the resilience as a dynamic process and emphasizes the interaction between the subject and the environment. To sum up, two necessary factors are included in the definition of the resilience: the individual suffers from the adverse situation or pressure, and successfully answers or adapts very well.

Funds Project: 2015 Heilongjiang Province Philosophy and Social Science Planning Project (15EDE07)

About the author: Lian Liu, female, the Han nationality, master, research direction: Psychological health education.
Some college students are poor in bearing setbacks and pressures, resulting in psychological problems or disorders, while the others can adapt very well. As a psychological trait of individuals in dealing with setbacks and adapting to the development successfully, the resilience should be paid attention to. Researches related to the resilience develop very fast during the past thirty years, because it has close relation with, protects and promotes the psychological health.

Improve the ability of resilience in responding to the pressure; the researches on the resilience help the active construction of students' strength. It has positive and profound practical significance in the prevention and reduction of the psychological problems and promotion of the psychological health.

The group psychology counseling includes the knowledge, theory and technology on the basis of psychology. It can improve college students' psychological quality, solve the emotional disturbance and exert the personal potential as well as improve the interpersonal relationship. The research discusses the intervention effect on college students' resilience through the guiding group of positive psychology. The positive group guidance includes the design of group guidance and the creation of group atmosphere. The positive psychology is used in all the things to which the leaders pay attention. With the help of interpersonal interaction in the group, individuals can change positively in the communication, improves the relations with others and learns new attitudes and behaviors.

\section{SCHEME DESIGN}

The scheme of group psychology counseling bases on the idea and method of positive psychology and combines with the reality of the school as well as the protective principle of resilience. Create the positive and warm atmosphere of group guidance and accept the response of the members, designing the scheme from the five dimensions of the resilience.

Purpose concentration-Learn the concept of positive psychology and train to focus on the positive aspects. 
Emotional control-Perceive the emotion, allow the existence of unhealthy emotions and learn the methods to deal with it.

Positive cognition-Learn the emotional ABC theory, actively adjust the cognition and train positive thinking.

Family support-Introspect the relation with parents and carry out gratitude training.

Interpersonal assistance-Find out methods to deal with interpersonal problems through brainstorm and learn to improve the ability in the interpersonal communication through face-to-face interaction.

\section{RESEARCH METHOD}

The recruitment object is the college students on campus who want to improve the mental ability, interpersonal skill, with good mental state instead of obvious psychological disorder. Design in accordance with the quasi experiment of the experimental psychology, pretest the resilience level and divide it into the experimental group and the control group. Carry out the intervention training of resilience on the experimental group and no intervention in the control group. Posttest the two groups, compare the resilience level before and after the intervention and test the intervention effects. Record the thinking, gain and growth of its members through the Group Activity Unit Record Chart to carry out qualitative evaluation. Carry out the quantitative evaluation before and after the test on students in the experimental group through the Adolescent Resilience Scale, and at length use SPSS statistical software to analyze.

\section{RESEARCH RESULTS}

\section{A. Independent Sample T in the Pre-post Test of Resilience in the Control Group}

TABLE 1 INDEPENDENT SAMPLE T IN THE PRE-POST TEST OF RESILIENCE IN THE CONTROL GROUP

\begin{tabular}{|c|c|c|c|c|c|}
\hline & $\begin{array}{c}\text { Pre-post } \\
\text { test }\end{array}$ & Mean value & $\begin{array}{l}\text { Standard } \\
\text { deviation }\end{array}$ & $\mathbf{t}$ & $\begin{array}{c}\text { Sig. } \\
\text { (Bilateral) }\end{array}$ \\
\hline \multirow{2}{*}{$\begin{array}{l}\text { Purpose } \\
\text { concentration }\end{array}$} & Pre-test & 18.1613 & 2.65953 & \multirow[t]{2}{*}{.309} & \multirow[t]{2}{*}{.759} \\
\hline & Post-test & 17.9394 & 3.06124 & & \\
\hline \multirow{2}{*}{$\begin{array}{l}\text { Emotional } \\
\text { control }\end{array}$} & Pre-test & 23.6897 & 2.70057 & \multirow[t]{2}{*}{-.183} & \multirow[t]{2}{*}{.856} \\
\hline & Post-test & 23.8182 & 2.82239 & & \\
\hline \multirow{2}{*}{$\begin{array}{l}\text { Positive } \\
\text { cognition }\end{array}$} & Pre-test & 16.9355 & 2.11243 & \multirow[t]{2}{*}{.654} & \multirow[t]{2}{*}{.516} \\
\hline & Post-test & 16.5000 & 3.06910 & & \\
\hline \multirow{2}{*}{$\begin{array}{l}\text { Personal } \\
\text { strength }\end{array}$} & Pre-test & 58.7241 & 5.31102 & \multirow[t]{2}{*}{.353} & \multirow[t]{2}{*}{.726} \\
\hline & Post-test & 58.1563 & 7.03956 & & \\
\hline \multirow[t]{2}{*}{ Family support } & Pre-test & 24.1935 & 3.35081 & \multirow[t]{2}{*}{.212} & \multirow[t]{2}{*}{.832} \\
\hline & Post-test & 24.0000 & 3.89711 & & \\
\hline \multirow{2}{*}{$\begin{array}{l}\text { Interpersonal } \\
\text { assistance }\end{array}$} & Pre-test & 24.2258 & 2.94063 & \multirow[t]{2}{*}{-1.228} & \multirow[t]{2}{*}{.224} \\
\hline & Post-test & 25.2121 & 3.44381 & & \\
\hline \multirow{4}{*}{$\begin{array}{l}\text { Sustaining } \\
\text { strength } \\
\text { Total score }\end{array}$} & Pre-test & 48.4194 & 4.72422 & \multirow[t]{2}{*}{-.552} & \multirow[t]{2}{*}{.583} \\
\hline & Post-test & 49.2121 & 6.56105 & & \\
\hline & Pre-test & 107.0345 & 8.23964 & .001 & .999 \\
\hline & Post-test & 107.0313 & 10.96765 & & \\
\hline
\end{tabular}

According to the table 1 , no obvious difference exists in the resilience and dimensions of the control group in the prepost test. Resilience intervention is not implemented in the control group. The resilience does not change before and after the group psychology counseling.

\section{B. Independent Sample T in the Pre-post Test of Resilience in the Experimental Group}

TABLE 2 INDEPENDENT SAMPLE T IN THE PRE-POST TEST OF RESILIENCE IN THE EXPERIMENTAL GROUP

\begin{tabular}{|c|c|c|c|c|c|}
\hline & Pre-post & tMean value & $\begin{array}{l}\text { Standard } \\
\text { deviation }\end{array}$ & $\mathrm{t}$ & $\begin{array}{l}\text { Sig. } \\
\text { (Bilateral) }\end{array}$ \\
\hline \multirow{2}{*}{$\begin{array}{l}\text { Purpose } \\
\text { concentration }\end{array}$} & Pre-test & 18.3400 & 2.95966 & \multirow[t]{2}{*}{-3.527} & \multirow[t]{2}{*}{.001} \\
\hline & Post-test & 20.3846 & 2.35769 & & \\
\hline \multirow{2}{*}{$\begin{array}{l}\text { Emotional } \\
\text { control }\end{array}$} & Pre-test & 23.2800 & 2.19499 & \multirow[t]{2}{*}{-3.404} & \multirow[t]{2}{*}{.001} \\
\hline & Post-test & 24.9487 & 2.41649 & & \\
\hline \multirow{2}{*}{$\begin{array}{l}\text { Positive } \\
\text { cognition }\end{array}$} & Pre-test & 16.3800 & 2.53860 & \multirow[t]{2}{*}{-2.889} & \multirow[t]{2}{*}{.005} \\
\hline & Post-test & 17.7692 & 1.81313 & & \\
\hline \multicolumn{2}{|c|}{ Personal strength Pre-test } & 58.0000 & 6.11121 & \multirow[t]{2}{*}{-4.180} & \multirow[t]{2}{*}{.000} \\
\hline & Post-test & 63.1026 & 5.36458 & & \\
\hline \multirow[t]{2}{*}{ Family support } & Pre-test & 24.1600 & 3.47798 & \multirow[t]{2}{*}{-.224} & \multirow[t]{2}{*}{.823} \\
\hline & Post-test & 24.3077 & 2.47252 & & \\
\hline \multirow{2}{*}{$\begin{array}{l}\text { Interpersonal } \\
\text { assistance }\end{array}$} & Pre-test & 23.1800 & 1.87017 & \multirow[t]{2}{*}{-3.567} & \multirow[t]{2}{*}{.000} \\
\hline & Post-test & 25.0000 & 2.72416 & & \\
\hline \multirow{4}{*}{$\begin{array}{l}\text { Sustaining } \\
\text { strength } \\
\text { Total score }\end{array}$} & Pre-test & 47.3400 & 4.45664 & \multirow[t]{2}{*}{-2.100} & \multirow[t]{2}{*}{.039} \\
\hline & Post-test & 49.3077 & 4.29292 & & \\
\hline & Pre-test & 105.3400 & 8.52035 & -4.047 & .000 \\
\hline & Post-test & 112.4103 & 7.71096 & & \\
\hline
\end{tabular}

According to the table 2, except for the family support obvious differences exist in the total score of the positive cognition, interpersonal assistance and sustaining strength and resilience in the pre-post test.

\section{ANALySIS AND DisCUSSION ON THE RESILIENCE INTERVENTION TRAINING}

According to the pre-post test results of the control group students' resilience level is stable. The testees are coessential, because no intervention is carried out in the control group. Furthermore, the campus environment is peaceful, simple and harmonious, and the big events having great impact on students in the control group don't happen. The group psychology counseling should avoid the examinations and large-scale campus activities, to ensure the testee takes a test without great pressure.

The result shows except for the family support, the positive cognition, interpersonal assistance and sustaining strength of the resilience of the experimental group are different obviously As a dynamic resource for individuals to respond to the pressure, the resilience can be intervened and improved. The family support does not take effects because: Firstly, the group counseling cannot intervene in parents' attitudes but students'; secondly, some topics in the questionnaire applied to the intervention research remain to be improved, like "my parents always like to intervene in my opinions" and "my opinions are not important in my family", "my parents lack confidence in me and don't give me emotional support". It can measure parents' supporting degree but fails to reflect the intervention changes. Thirdly, the researchers need to design the group counseling scheme more roundly.

The comparative study between the experimental group and the control group shows the intervention experiment of the resilience has taken effect. 


\section{CONCLUSION}

1. In this activity, the students feel happy and relaxed and open mind to each other. I feel relaxed and pleasant because of the interesting classroom. All students are energetic and believe each other. The harmonious conversation brings us together.

2. I can see more clearly the merits of others and me and live more confidently. I know many people care for and accompany me. Let's make efforts to create the future and love ourselves.

According to the above research, it is effective to improve college students' resilience through the positive group psychology counseling. In the design of scheme, we should adhere to the protective principle of resilience and apply positive psychological intervention to the group psychology counseling. The group counseling in the future should improve the follow-up study. With respect to the improvement of scheme in the next step, in the family support training, train how to get support from the family members in the scenario simulation; in the interpersonal assistance, design tasks in need of teamwork and enrich the ways of interpersonal assistance. Positive group psychology counseling can improve college students' resilience. Continuous exploration can be conducted to check whether it is useful for other psychological processes. Actively improving the application of positive psychology counseling conforms to the positive psychology development.

\section{REFERENCES}

[1] Fan Fumin. Development of Group Counseling in China: Retrospect and prospect [J], Journal of Tsinghua University (philosophy and social science edition), Jun.2005: 62-69

[2] Liu Lian. Research on the Relations of the Life Events, Resilience and Emotion of College Students [D], Harbin Engineering University, 2012

[3] Christopher Peterson. Positive Psychology [M], translated by Xu Hong. Beijing: Qunyan Press, 2010: 40-41

[4] Fu Yanfen, Yin Keli, Wang Jianhua, Tang Jun, Liao Jianying. Analysis on the Literature Metrology of Positive Psychology in China [J], Journal of Dali University, Feb.2012: 93-96. 